\title{
ROLE OF LEVEL V LYMPH NODE DISSECTION IN N1b PAPILLARY THYROID CARCINOMA
}

\author{
By \\ Eid R. El-Gammal Hammed*, M. El-Azonny* and Ahmed T. Al- \\ Shamy** \\ *Surgical Oncology Department, Faculty of Medicine, Al Azhar University, Egypt, and \\ ** Surgical Oncology Department, Tanta Cancer Center, Egypt \\ Corresponding author: Eid R. El-Gammal \\ Email: dr_eed2014@yahoo.com
}

Phone number: 01222676072

\begin{abstract}
Background: For the N1b papillary thyroid carcinoma (PTC) patients, modified radical neck dissection (MRND) encompassing levels II - V is generally recommended. However, routine level V dissection is controversial because of the low incidence of metastasis/recurrence in level $\mathrm{V}$ and the increased morbidities associated with level $\mathrm{V}$ dissection.

Objective: This study was designed to determine the clinical risks and benefits of routine level $\mathrm{V}$ dissection in N1b PTC patients with clinical negative level V.

Patients and Methods: This study was a prospective, comparative, randomized and descriptive study of 40 patients suffering N1b papillary thyroid carcinoma. The patients were divided into two equal groups: Group 1 subjected to MRND, and Group 2 subjected to SND. Both groups were compared for age, sex, intraoperative (duration of surgery and complications) and postoperative results (complications and distribution of lateral nodal recurrence).

Results: Under a matched condition, occult level V metastasis was observed in 5.0\%. The MRND group exhibited a significantly longer operation time compared with the SND group. The amount of drainage was significantly more in the MRND group compared with the SND group. Time of drain removal was significantly less in the SND group compared to MRND group. Chyle leak was more frequent in the MRND group compared with the SND group but not statically significant. Level V recurrences did not occur in 3 recurred N1b PTC patients who underwent unilateral MRND and SND. Shoulder syndrome encompassing shoulder dysfunction and pain was significantly more frequent in the MRND group than in the SND group. There were no statistically difference between the groups according to infection, transient hypocalcaemia, transient RLN palsy and nodal recurrence.
\end{abstract}

Conclusion: Because of the low incidence of metastasis/recurrence in level $\mathrm{V}$ and the clear evidence of increased morbidities, level $\mathrm{V}$ dissection in N1b PTC patients may be reserved for those clinically/radiologically evident metastasis in level V.

Key words: Papillary thyroid carcinoma, lateral lymph node metastasis, level V dissection, level V metastasis, modified radical neck dissection, selective radical neck dissection. 


\section{INTRODUCTION}

Thyroid carcinoma is the most common type of malignant endocrine tumors, accounts for $1 \%$ of all human malignant tumors and $33 \%$ of the head and neck malignant tumors. Among the thyroid carcinoma, $80-85 \%$ are papillary thyroid carcinoma (PTC) (Liu et al., 2019). In Egypt, thyroid cancer is the fifth most frequent cancer in females accounting for $3.6 \%$ of all malignancy in women. With an incidence that ranged between 3.5\% in upper Egypt in 2008 to $3.9 \%$ in 2011 in lower Egypt (Mohamed et al., 2016). PTC shows a mild biological behavior and has an excellent prognosis. Adequate management leads to a survival rate in excess of $90 \%$. Death due to PTC is very rare. However, cervical lymph nodal metastases are common (Pacini et al., 2018). Cervical lymph node metastases are found in 20-50 per cent of cases and in up to 90 per cent when micro-metastases are included. Cervical lymph node metastases are considered an independent risk factor for loco-regional recurrence and increased morbidity. Many population-based studies demonstrated that cervical lymph node metastasis has a negative effect on survival with varying levels of significance (Mansour al., 2018). In general, therapeutic lateral neck dissection is recommended for PTC patients if lateral compartment LN metastases are confirmed by clinical examination or radiological evaluation (Won et al., 2019). MRND refers to the excision of the lateral neck LNs, including levels II $-\mathrm{V}$, with preservation of one or more non-lymphatic structures, such as the spinal accessory nerve, internal jugular vein, or sternocleidomastoid muscle. While, SND refers to the excision of suspicious lateral neck LNs accompanied by preservation of one or more of the $\mathrm{LN}$ groups that are routinely removed in MRND. Level I dissection is generally excluded from MRND because of the rarity of metastatic disease (Ahmadi et al., 2011). Level $\mathrm{V}$ has been particularly controversial in therapeutic lateral neck dissection in PTC patients as level V dissection is the main procedures leading to postoperative complications due to injuries of the spinal accessory nerve (Gane et al., 2018). Therefore, a number of studies have examined the distribution of metastatic LN and the possibility of omitting level $\mathrm{V}$ during neck dissection. However, there have been no clear conclusions, and this remains a subject of ongoing debate (Bozkurt, 2019).

\section{THE AIM OF THIS STUDY}

Was to determine the clinical risks and benefits of routine level $\mathrm{V}$ dissection in N1b PTC patients.

\section{PATIENTS AND METHODS}

This study was approved by the institutional review board at Al-Azhar University Hospitals. We conducted a retrospective cohort study, by analyzing data collected between September 2017 and September 2019. A total of 40 patients who met the following inclusion and exclusion criteria were enrolled.

\section{Inclusion criteria:}

1. Performance Status (PS) I or II.

2. Age blew 60 years old.

3. Pathologically proven PTC.

4. Clinically and pathologically proven unilateral lateral cervical LN metastasis (levels II - IV). 
5. Clinically and radiologically free level $\mathrm{V}$ cervical LN.

\section{Exclusion criteria:}

1. Performance status (PS) III or IV.

2. Age above 60 years old.

3. History of previous neck surgery.

4. Non-PTC carcinomas (follicular/ medullary/ anaplastic).

5. Bilateral cervical LNs metastasis.

6. Distant metastasis.

Patients were randomly classified into two groups, The first group included twenty patients and they have been submitted for total thyroidectomy with central neck dissection and unilateral MRND (levels II - V dissection) and the second group included twenty patients and they have been submitted for total thyroidectomy with central neck dissection and unilateral SND (levels II IV dissection). Lateral neck dissection before total thyroidectomy and central neck dissection were performed. Lateral neck dissection included modified radical neck dissection (MRND) and selective neck dissection (SND). Level I dissection was not performed. During surgery, the cervical LN levels present in the dissected specimens were classified individually with a labeling suture. The thyroid specimen and cervical lymph nodes removed were assessed for: cell type of the main lesion, primary tumor size (longest diameter of the largest lesion), location, multifocality, bilaterality, extra thyroid extention (ETE), lymphovascular invasion and regional LNs metastasis. After the initial surgery, all patients underwent regular follow-within 12 months with clinical evaluations including physical examinations, ultrasound (US), computed tomography (CT), iodine-131 scan and serum thyroglobulin testing. After total thyroidectomy, thyroid stimulating hormone suppression therapy (serum thyroid stimulating hormone level $<0.5 \mathrm{mU} / \mathrm{l})$ by levothyroxine with radioactive iodine (RAI) ablation as an initial postoperative therapy. Recurrence is defined as the presence of metastatic $\mathrm{LN}$ by cytological examination from a fine needle aspiration biopsy. Statistical analysis was performed using SPSS version 22.0. Statistically significant differences were defined as those with $\mathrm{p}<$ 0.05 . Continuous variables were presented as mean \pm standard deviation (SD), whereas categorical variables were presented as the number of cases with percentage. The chi-square test was used to compare differences between categorical variables, whereas Student's ttest was used to test the significance between continuous variables. Fisher's exact test was used when expected cell count of more than $25 \%$ of cases was less than 5 . 


\section{RESULTS}

Clinicopathological characteristics of patients in both groups:

In MRND group, $15(75.0 \%)$ were women and $5(25.0 \%)$ were men. The mean age was 39.25 years, Right sided MRND was performed in $12(60.0 \%)$ patients, whereas left-sided MRND was performed in $8(40.0 \%)$ patients. The mean tumor size was $3.11 \mathrm{~cm}$ ranging from $2 \mathrm{~cm}$ to $4 \mathrm{~cm}$. Bilaterality, multiplicity, microscopic ETE,CLT and LVI\&CI were seen in $4(20.0 \%), 5$ $(25.0 \%), 13(65 \%), 2(10.0 \%)$ and 20 (100.0\%) patients, respectively. Of 20 patients, pathology of PTCs were 16 (80\%) conventional PTC, 2 (10.00\%) follicular variant, 1 (5.0\%) diffuse sclorising and 1(5.0\%) tall cell variant .In SND group, 14 (70.0\%) were women and $6(30.0 \%)$ were men. The mean age was 41.5 years, Right sided SND was performed in $5(25.0 \%)$ patients, whereas left-sided SND was performed in 15 (75.0 $\%)$ patients. The mean tumor size was $3.21 \mathrm{~cm}$ ranging from 2 to $4 \mathrm{~cm}$. Bilaterality, multiplicity, microscopic ETE,CLT and LVI\&CI were seen in 6 (30.0\%), 4 (20.0\%), 15 (75.0\%), 3 $(15.0 \%)$ and $20 \quad(100.0 \%)$ patients, respectively. Of 20 patients, pathology of PTCs were 17 (85.0\%) conventional PTC, $2(10.0 \%)$ follicular variant, $1(5.0 \%)$ diffuse sclorising and $0(0.0 \%)$ tall cell variant (Table1).

\section{Table (1): Clinicopathological characteristics of patients in both groups}

\begin{tabular}{|c|c|c|}
\hline $\begin{array}{ll}\begin{array}{l}\text { Clinicopathologic } \\
\text { characteristics }\end{array} & \text { Groups } \\
\end{array}$ & $\begin{array}{l}\text { MRND } \\
\text { group } \\
\text { N }(\%)\end{array}$ & $\begin{array}{l}\text { SND group } \\
\mathbf{N}(\%)\end{array}$ \\
\hline $\begin{array}{l}\text { sex } \\
\text { female } \\
\text { male }\end{array}$ & $\begin{array}{l}15(75 \%) \\
5(25 \%)\end{array}$ & $\begin{array}{l}14(70 \%) \\
6(30 \%)\end{array}$ \\
\hline $\begin{array}{l}\text { Age }(\text { Mean } \pm \text { SD) } \\
<45 \\
\geq 45\end{array}$ & $\begin{array}{l}39.25 \pm 11.46 \\
13(65 \%) \\
7(35 \%)\end{array}$ & $\begin{array}{l}41.5 \pm 10.9 \\
11(55 \%) \\
9(45 \%)\end{array}$ \\
\hline Size $($ Mean \pm SD $)$ & $3.11 \pm 0.6103$ & $3.21 \pm 0.6037$ \\
\hline $\begin{array}{l}\text { Side } \\
\text { Right } \\
\text { Left }\end{array}$ & $\begin{array}{l}12(60 \%) \\
8(40 \%)\end{array}$ & $\begin{array}{l}5(25 \%) \\
15(75 \%)\end{array}$ \\
\hline Bilaterality & $4(20.0 \%)$ & $6(30.0 \%)$ \\
\hline Multiplicity & $5(25.0 \%)$ & $4(20.0 \%)$ \\
\hline $\begin{array}{l}\text { PTC Variant } \\
\text { Conventional } \\
\text { Follicular } \\
\text { Diffuse sclerosing } \\
\text { Tall cell }\end{array}$ & $\begin{array}{l}16(80 \%) \\
2(10.00 \%) \\
1(5.0 \%) \\
1(5.0 \%)\end{array}$ & $\begin{array}{l}17(85.0 \%) \\
2(10.0 \%) \\
1(5.0 \%) \\
0(0.0 \%)\end{array}$ \\
\hline $\begin{array}{l}\text { Associated lesions } \\
\text { CLT } \\
\text { ETE } \\
\text { LVI \& CI }\end{array}$ & $\begin{array}{l}2(10.0 \%) \\
13(65.0 \%) \\
20(100.0 \%)\end{array}$ & $\begin{array}{l}3(15.0 \%) \\
15(75.0 \%) \\
20(100.0 \%)\end{array}$ \\
\hline
\end{tabular}

PTC, Papillary thyroid carcinoma; MRND, Modified radical neck dissection; SND, Selective neck dissection; SD, Standard Deviation; CLT, Chronic Lymphocytic thyroiditis; ETE, extra thyroidal extension; LVI, Lymphovascular invasion; CI, Capsular invasion 
Distribution of lateral LNs metastasis in in both groups:

In MRND group, Level III lateral neck nodes were involved in 16 cases $(80.0 \%)$. However level IV and level II were involved in 15 cases $(75.0 \%)$ and in 11 cases $(55.0 \%)$ respectively. Of the 20 dissections, $4(20.3 \%)$ and $16(80.0 \%)$, had nodal metastases in single and multiple levels, respectively. Skip metastases, defined as lateral LN metastasis without central LN metastasis, were found in two cases (10\%). Even when preoperative US and CT did not show any evidence of metastasis in level $\mathrm{V}$, occult metastatic LNs were detected in one case (5.0\%). In SND group, 6 (30.0 $\%)$ and $14(70.0 \%)$, had metastatic LNs single level and multiple levels, respectively. Level III metastases were evident in 17 cases (85.0\%) while level IV and II were evident in $13(65.5 \%)$ and 12 (60.2) cases respectively. Skip metastases were found in one case $(5.0 \%)$. (Table 2).

Table (2): Distribution of lateral LNs metastasis both groups.

\begin{tabular}{|c|c|c|}
\hline $\begin{array}{ll}\text { Distribution of lateral } \\
\text { LN metastasis }\end{array}$ & $\begin{array}{c}\text { MRND group } \\
\mathbf{N}(\%)\end{array}$ & $\begin{array}{c}\text { SND group } \\
\mathbf{N}(\%)\end{array}$ \\
\hline $\begin{array}{l}\text { Regional LN Mets } \\
\text { Central } \\
\text { Lateral }\end{array}$ & $\begin{array}{l}18(90 \%) \\
20(100 \%)\end{array}$ & $\begin{array}{l}19(95 \%) \\
20(100 \%)\end{array}$ \\
\hline Skip Mets & $2(10 \%)$ & $1(5 \%)$ \\
\hline $\begin{array}{l}\text { Lateral LN Mets } \\
\text { Level II } \\
\text { Level III } \\
\text { Level IV } \\
\text { Level V }\end{array}$ & $\begin{array}{l}11(55 \%) \\
15(75 \%) \\
16(80 \%) \\
1(5 \%)\end{array}$ & $\begin{array}{l}12(60 \%) \\
13(65 \%) \\
17(85 \%)\end{array}$ \\
\hline $\begin{array}{l}\text { Simultaneous lateral Mets } \\
\text { Single level } \\
\text { Multiple level }\end{array}$ & $\begin{array}{l}4(20 \%) \\
16(80 \%)\end{array}$ & $\begin{array}{l}6(30 \%) \\
14(70 \%)\end{array}$ \\
\hline
\end{tabular}

Distribution of lateral neck recurrence in both groups:

In MRND group, the median follow-up time was 18.2 months. Lateral neck recurrence was found in $1(5.0 \%)$ and it was ipsilateral and occurred in level III. In
SND group, the median follow-up time was 17.95 months. Lateral neck recurrence was found in $2(10.0 \%)$ and they were ipsilateral and occurred in level II and level III (Table 3). 
Table (3): Distribution of lateral neck recurrence in both groups.

\begin{tabular}{|l|l|l|l|l|}
\hline & $\begin{array}{c}\text { Groups } \\
\mathbf{N}(\%)\end{array}$ & $\begin{array}{c}\text { SND group } \\
\mathbf{N}(\%)\end{array}$ & X2 & P-value \\
\cline { 1 - 3 } Nodal recurrence & $1(5.0 \%)$ & $2(10.0 \%)$ & 0.36 & 0.55 \\
\cline { 1 - 3 } Positive & $19(95.0 \%)$ & $18(90.0 \%)$ & & \\
\hline
\end{tabular}

MRND, Modified radical neck dissection; SND, Selective neck dissection

Surgery-related outcomes in both
groups:

Under a matched condition, the MRND group exhibited a significantly longer operation time (221.25 $\mathrm{min}$ vs. 172.35 min, $\mathrm{p}<0.00001)$ compared with the SND group. The amount of drainage was significantly more in the MRND group compared with the SND group (321ml vs. $271.5 \mathrm{ml}, \mathrm{p}=0.033986)$. Time of drain removal was significantly less in the SND group compared to MRND group (3.95 days vs. 4.65 days, $\mathrm{p}=0.016358$ ). There was no statically difference between the two groups according to post op hospital stay and follow up (3.8days vs. 3.05 days, $\mathrm{p}=0.093345)$ and $(18.2 \mathrm{mon} \pm 3.4883$ vs. $17.95 \pm 3.4713, \mathrm{p}=0.821497)$ respectively. Chyle leak was more frequent in the MRND group compared with the SND group but not statically significant $(10 \%$ vs. $0.0 \%, \mathrm{p}=0.2308)$.Furthermore, "shoulder syndrome" encompassing shoulder dysfunction and pain, was significantly more frequent in the MRND group compared with the SND group (30.0\% vs. $0.0 \%, p=0.0202)$.there were no cases of intra and post-operative hemorrhage, nerve injury (symphatic chain, vagus, phrenic and brachial plexus) and adjacent structure injury ( Trachea, Esophagus, Carotid artery and IJV ) in both groups .there were no statically difference between the MRND group and SND group according to infection, Transient hypocalcaemia, Transient RLN palsy and nodal recurrence $(10.0 \%$ vs. $5.0 \% \mathrm{p}=0.548),(30.0 \%$ vs. $35.0 \% \mathrm{p}=$ $0.735),(5.0 \%$ vs. $0.0 \% \mathrm{p}=1.0)$ and $(5.0 \%$ vs. $10.0 \% \mathrm{p}=0.548$ ) respectively (Table 4 ). 
ROLE OF LEVEL V LYMPH NODE DISSECTION IN N1b PAPILLARY...

Table (4): Surgery-related outcomes in both groups.

\begin{tabular}{|c|c|c|c|}
\hline Surgery related outcomes & MRND group & SND group & P-value \\
\hline $\begin{array}{l}\text { Operative time (min) } \\
\text { mean } \pm \text { SD }\end{array}$ & $221.25 \pm 27.52$ & $172.35 \pm 25.275$ & $<0.001$ \\
\hline $\begin{array}{l}\text { Drainage amount (ml) } \\
\text { mean } \pm \text { SD }\end{array}$ & $321 \pm 72.1766$ & $271.5 \pm 70.133$ & 0.034 \\
\hline $\begin{array}{l}\text { Time of drain removal (day) } \\
\text { mean } \pm S D\end{array}$ & $4.65 \pm 0.9333$ & $3.95 \pm 0.8255$ & 0.016 \\
\hline $\begin{array}{l}\text { Post op hospital stay (day) } \\
\text { mean } \pm \text { SD }\end{array}$ & $3.8 \pm 1.281$ & $3.05 \pm 1.468$ & 0.093 \\
\hline $\begin{array}{l}\text { Follow up (month) } \\
\text { mean } \pm \mathrm{SD}\end{array}$ & $18.2 \pm 3.4883$ & $17.95 \pm 3.4713$ & 0.821 \\
\hline $\begin{array}{l}\text { Transient hypocalcaemia } \\
\text { Positive } \\
\text { Negative }\end{array}$ & $\begin{array}{l}6(30.0 \%) \\
14(70.0 \%)\end{array}$ & $\begin{array}{l}7(35.0 \%) \\
13(65.0 \%)\end{array}$ & 0.73 \\
\hline $\begin{array}{l}\text { Permanent hypocalcaemia } \\
\text { Positive } \\
\text { Negative }\end{array}$ & $\begin{array}{l}1(5.0 \%) \\
19(95.0 \%)\end{array}$ & $\begin{array}{l}2(10.0 \%) \\
18(90.0 \%)\end{array}$ & 0.55 \\
\hline $\begin{array}{l}\text { Permanent RLN palsy } \\
\text { Positive } \\
\text { Negative }\end{array}$ & $\begin{array}{l}1(5.0 \%) \\
19(95.0 \%)\end{array}$ & $\begin{array}{l}0(0.0 \%) \\
20(100.0 \%)\end{array}$ & $>0.05$ \\
\hline $\begin{array}{l}\text { Chyle leak } \\
\text { Positive } \\
\text { Negative } \\
\end{array}$ & $\begin{array}{l}2(10.0 \%) \\
18(90.0 \%)\end{array}$ & $\begin{array}{l}0(0.0 \%) \\
20(100.0 \%)\end{array}$ & $>0.05$ \\
\hline $\begin{array}{l}\text { Wound infection } \\
\text { Positive } \\
\text { Negative }\end{array}$ & $\begin{array}{l}2(10.0 \%) \\
18(90.0 \%)\end{array}$ & $\begin{array}{l}1(5.0 \%) \\
19(95.0 \%)\end{array}$ & 0.55 \\
\hline $\begin{array}{l}\text { Shoulder syndrome } \\
\text { Positive } \\
\text { Negative }\end{array}$ & $\begin{array}{l}6(30.0 \%) \\
14(70.0 \%)\end{array}$ & $\begin{array}{l}0(0.0 \%) \\
20(100.0 \%)\end{array}$ & $<0.05$ \\
\hline
\end{tabular}

MRND, Modified radical neck dissection; SND, Selective neck dissection; SD, Standard Deviation

\section{DISCUSSION}

The patients with PTC have a relatively excellent prognosis with a 10year overall survival rate exceeding $90 \%$. However, cervical lymph node metastases are found in 30 to $80 \%$ of patients when diagnosed including occult metastases (Moo et al., 2010). Cervical LNM in PTC has been found to be one of the most significant factors for locoregional recurrence, and it also has been regarded as the first sign of a potentially lethal outcome (Grant, 2015). Therefore, an effective therapeutic lateral neck dissection is critical. However, overly aggressive operations such as blindly enlarging the extent of lateral neck dissection may lead to clinically important postoperative morbidities because of injury to the spinal accessory nerve or the cervical plexus, despite gross preservation of these nerves (Zhang et al., 2013). There are various options in the extent of therapeutic lateral neck dissection in PTC. Whether or not level V should be included in the lateral neck dissection when it is clinically free continues to be debated 
(Eltelety and Terris, 2019). Therefore, we designed the current study to determine whether routine level $\mathrm{V}$ dissection should be included in MRND for clinically suspicious N1b PTC patients. Skip metastases were found in 3 cases $(7.5 \%)$ patients, a finding that is consistent with results from Park et al. (2012). In contrast to our study, Xiang et al. (2015) reported that the rate reached up to $25 \%$. Of 40 patients, pathology of PTCs were 33 $(82.5 \%)$ conventional PTC, $3 \quad(7.5 \%)$ follicular variant, $2(5.0 \%)$ diffuse sclorising and $1(2.5 \%)$ tall cell variant in agreement with kim et al. (2017). We also observed simultaneous multi-level metastasis in 30 cases $(75 \%)$. Previous studies regarding lateral $\mathrm{LN}$ metastasis patterns have reported an incidence of multi-level lateral $\mathrm{LN}$ metastasis in $\mathrm{N} 1 \mathrm{~b}$ PTC patients that exceeds $80 \%$ (King et al., 2011). In MRND group, Level III lateral neck nodes were involved in 16 cases (80.0\%).However level IV and level II were involved in 15 cases $(75.0 \%)$ and 11 cases $(55.0 \%)$ respectively. In SND group, Level III metastases were evident in 17 cases $(85.0 \%)$ while level IV and II were evident in $13(65.5 \%)$ and 12 (60.2) cases respectively. A meta-analysis also reported that lateral $\mathrm{LN}$ metastasis predominantly involves levels III and IV (Eskander et al., 2013). Wang et al. (2019) reported the overall rates of LNM in levels II, III, IV and V were $50.8 \%$, $63.9 \%, 72.8 \%$ and $21.3 \%$, respectively. Level IV was the most frequently involved region, followed by levels III and II. In contrast to our study, Merdad et al. (2012) reported $49 \%$ and $29 \%$ involvement of levels II and V, respectively, in a large series of patients undergoing therapeutic lateral neck dissection. Occult metastatic LNs in level $\mathrm{V}$ were detected in one case $(5.0 \%)$ in 20 patients whom underwent MRND. Khafif et al. (2013) reported that the incidence of overall level $\mathrm{V}$ metastasis was $13.9 \%$ and that of occult level $\mathrm{V}$ metastasis was only $8.6 \%$ in this study. Moreover, only $7.7 \%$ level $\mathrm{V}$ recurrences were observed among the recurred N1b PTC patients who underwent unilateral MRND. In contrast to our study, level $\mathrm{V}$ showed high incidence of nodal metastasis of approximately up to $53 \%$ reported by Yüce et al. (2010). The incidence of lateral neck recurrence in 20 patients who underwent MRND in our study was 1 (5.0 $\%)$ and it was ipsilateral and occurred in level III in agreement with $X u$ et al. (2017). However, we note that a higher incidence of recurrence after MRND has been seen by Javid et al. (2016). Shoulder syndrome defined as chronic painful and limited shoulder movement, was significantly more frequent in N1b PTC patients who underwent routine level $\mathrm{V}$ dissection than whom did not perform level $\mathrm{V}$ dissection $(30.0 \%$ vs. $0.0 \%, \mathrm{p}=$ 0.0202). As shown in many studies, level $\mathrm{V}$ dissection, which involves clearance of the posterior triangle, has the potential to increase the risk of spinal accessory nerve injury, despite gross preservation (Gane et al., 2019). Injury to the spinal accessory nerve can lead to a dropped shoulder and the inability to raise the arm above 90 degrees. Furthermore, spinal accessory nerve-associated morbidity has a negative impact on patients' social activities, decreasing their ability to participate in daily and leisure activities and also having a negative impact on work ability (Gane et al., 2017). Robinson et al. (2018) suggest that temporary or permanent 
spinal accessory nerve injury can be caused by dissection and retraction in up to $20 \%$ of dissections. The MRND group exhibited a significantly longer operation time (221.25 $\mathrm{min}$ vs. $172.35 \mathrm{~min}, \mathrm{p}<$ 0.00001) compared with the SND group in agreement with Kim et al. (2017) as level $\mathrm{V}$ dissection need more time during MRND. In our study, the amount of drainage was significantly more in the MRND group compared with the SND group $(321 \mathrm{ml}$ vs. $271.5 \mathrm{ml}, \mathrm{p}=0.033986)$ in agreement with Tamplen et al. (2017). While, kim et al. (2017) reported that there was no difference in the two groups according to the amount of drainage. In our study, Time of drain removal was significantly less in the SND group compared to MRND group (3.95 days vs. 4.65 days, $\mathrm{p}=0.016358)$ in agreement with Tamplen et al. (2017). In contrast to our study, Panda et al. (2015) reported that there was no difference in the two groups according to time of drain removal. Chyle leak from iatrogenic thoracic duct injury is a rare but serious complication of head and neck surgery that occurs in $0.5-1.4 \%$ of thyroidectomies and 2-8\% of neck dissections (Rammal et al., 2014). Chyle leak was more frequent in the MRND group compared with the SND group but not statistically significant ( $10 \%$ vs. 0.0 $\%, \quad \mathrm{p}=0.2308)$ in agreement with McNamara et al. (2016). Transient hypocalcaemia occurred in 13 cases $(32.5 \%)$ in agreement with Giordano et al. (2012). Permrnant hypocalcaemia occurred in 3 cases $(7.5 \%)$ in agreement with kim et al. (2017). In contrast, Ardito et al. (2016) observed that hypocalcemia was also highest in patients who underwent combined central and lateral ND combined with total thyroidectomy
(46.2\%). Possible explanation of hypoparathyroidism occurs after performing lateral ND is that the nodal clearance between the internal jugular vein and the carotid artery may disturb the inferior thyroid artery at its origin, thereby interrupting its blood supply. The parathyroid vessels are tiny and terminal, and being preserved in the dissected area, respond to the injury by disrupting blood supply to the glands, prolonging the ischemic damage, with significant parathyroid morbidity (Ardito et al., 2016). In our study there were no cases of permanent RLN palsy, nerve injury (Horner syndrome, Vagus nerve and Brachial plexus) and intra or pot operative bleeding. Wound infection occurred in 3 cases in both groups (7.5\%). McMullen et al. (2017) reported also 3 cases $(4.8 \%)$, those cases required treatment with antibiotics and close monitoring.

\section{CONCLUSION}

In clinically suspicious N1b PTC patients, levels II, III, and IV may be comprehensively dissected. However, because of the low incidence of metastasis and recurrence in level $\mathrm{V}$ and the clear evidence of increased morbidities from level $\mathrm{V}$ dissection, level $\mathrm{V}$ dissection in N1b PTC patients may be reserved for patients clinically and radiologically evident metastasis in level V. However, large prospective phase III trial is recommended to confirm that conclusion.

\section{REFERENCES}

1. Ahmadi N, Grewal A and Davidson BJ (2011): Patterns of cervical lymph node metastases in primary and recurrent papillary thyroid cancer. Journal of Oncology, 94(8): 683-691. 
2. Ardito G, Revelli L, Polistena A, Lucchini R, Giustozzi E, Guidi ML and Avenia N (2016): Complications of neck dissections in papillary thyroid carcinoma: a modified procedure to reduce parathyroid morbidity. Vivo, 30(3): 303-308.

3. Bozkurt B (2019): Therapeutic Neck Dissection for Differentiated Thyroid Cancer, to Whom and to What Extent? Thyroid and Parathyroid Diseases, 22(4): 225-231.

4. Eltelety AM and Terris DJ (2019): Neck Dissection in the Surgical Treatment of Thyroid Cancer. Endocrinology and Metabolism Clinics, 48(1): 143-151.

5. Eskander A, Merdad M, Freeman JL and Witterick IJ (2013): Pattern of spread to the lateral neck in metastatic well-differentiated thyroid cancer: a systematic review and metaanalysis. Thyroid, 23(5): 583-592.

6. Gane EM, McPhail SM, Hatton AL, Panizza BJ and O'Leary SP (2018): The relationship between physical impairments, quality of life and disability of the neck and upper limb in patients following neck dissection. Journal of Cancer Survivorship, 12(5): 619-631.

7. Gane EM, McPhail SM, Hatton AL, Panizza BJ and O'Leary SP (2019): Neck and Shoulder Motor Function following Neck Dissection: A Comparison with Healthy Control Subjects. Otolaryngology-Head and Neck Surgery, 160(6): 1009-1018.

8. Gane EM, Michaleff ZA, Cottrell MA, McPhail SM, Hatton AL, Panizza BJ and O'Leary SP (2017): Prevalence, incidence, and risk factors for shoulder and neck dysfunction after neck dissection: a systematic review. European Journal of Surgical Oncology, 43(7): 1199-1218.

9. Giordano D, Valcavi R, Thompson GB, Pedroni C, Renna L, Gradoni $P$ and Barbieri V (2012): Complications of central neck dissection in patients with papillary thyroid carcinoma: results of a study on 1087 patients and review of the literature. Thyroid, 22(9): 911-917.
10. Grant CS. (2015): Recurrence of papillary thyroid cancer after optimized surgery. Gland surgery, 4(1): 52-60.

11. Harris $T$, Doolarkhan $Z$ and Fagan JJ (2011): Timing of removal of neck drains following head and neck surgery. Ear, Nose \& Throat Journal, 90(4): 186-189.

12. Javid M, Graham E, Malinowski J, Quinn CE, Carling T, Udelsman $R$ and Callender GG (2016): Dissection of levels II through V is required for optimal outcomes in patients with lateral neck lymph node metastasis from papillary thyroid carcinoma. Journal of the American College of Surgeons, 222(6): 10661073.

13. Khafif A, Medina JE, Robbins KT, Silver CE, Weber RS, Rinaldo A and Ferlito A (2013): Level $\mathrm{V}$ in therapeutic neck dissections for papillary thyroid carcinoma. Head \& neck, 35(4): 605-607.

14. Kim SK, Park I, Hur N, Lee JH, Choe JH, Kim JH and Kim JS (2017): Should level V be routinely dissected in N1b papillary thyroid carcinoma? Thyroid, 27(2): 253-260.

15. King JM, Corbitt C and Miller FR (2011): Management of lateral cervical metastases in papillary thyroid cancer: patterns of lymph node distribution. Ear, Nose \& Throat Journal, 90(8): 386-389.

16. Liu C, Xiao C, Chen J, Li X, Feng Z, Gao $Q$ and Liu $Z$ (2019): Risk factor analysis for predicting cervical lymph node metastasis in papillary thyroid carcinoma: a study of 966 patients. BMC cancer, 19(1): 622-631.

17. Mansour J, Sagiv D, Alon E and Talmi Y (2018): Prognostic value of lymph node ratio in metastatic papillary thyroid carcinoma. The Journal of Laryngology \& Otology, 132(1): 8-13.

18. McMullen C, Rocke $D$ and Freeman J (2017): Complications of bilateral neck dissection in thyroid cancer from a single high-volume center. JAMA OtolaryngologyHead \& Neck Surgery, 143(4): 376-381.

19. McNamara WF, Wang LY, Palmer FL, Nixon IJ, Shah JP, Patel SG and Ganly I (2016): Pattern of neck recurrence after lateral neck dissection for cervical metastases 
in papillary thyroid cancer. Surgery, 159(6): $1565-1571$

20. Merdad M, Eskander A, Kroeker T and Freeman JL (2012): Predictors of level II and $\mathrm{Vb}$ neck disease in metastatic papillary thyroid cancer. Archives of OtolaryngologyHead \& Neck Surgery, 138(11): 1030-1033.

21. Mohamed RAEA, Backeet RAE and Elsaayed WAE (2016): Risk factors of differentiated thyroid cancer in Sohag, Egypt. Int. J. Curr. Res. Med. Sci. 2(11), 27-34.

22. Moo TA, McGill J, Allendorf J, Lee J, Fahey $T$ and Zarnegar $R$ (2010): Impact of prophylactic central neck lymph node dissection on early recurrence in papillary thyroid carcinoma. World Journal of Surgery, 34(6): 1187-1191.

23. Pacini F, Basolo F, Bellantone R, Boni G, Cannizzaro MA, De Palma $M$ and Fugazzola L (2018): Italian consensus on diagnosis and treatment of differentiated thyroid cancer: joint statements of six Italian societies. Journal of Endocrinological Investigation, 41(7): 849-876.

24. Panda NK, Sood M, Kaushal D, Bakshi J and Verma RK (2015): How Long to Keep the Surgical Drains-Looking for Evidence. Journal of Otolaryngology-ENT Research, 2(3): $20-25$.

25. Park JH, Lee YS, Kim BW, Chang HS and Park CS (2012): Skip lateral neck node metastases in papillary thyroid carcinoma. World journal of surgery, 36(4): 743-747.

26. Rammal A, Zawawi F, Varshney R, Hier MP, Payne RJ and Mlynarek AM (2014): Chyle leak: a rare complication posthemithyroidectomy. case report and review of literature. Otolaryngologia Polska, 68(4): 204-207.

27. Robinson M, Ward L, Mehanna H, Paleri $\mathrm{V}$ and Winter SC (2018): Provision of physiotherapy rehabilitation following neck dissection in the UK. The Journal of Laryngology \& Otology, 132(7): 624-627.
28. Tamplen ML, Tamplen J, Shuman E, Heaton CM, George JR, Wang SJ and Ryan WR (2017): Comparison of Output Volume Thresholds for Drain Removal After Selective Lateral Neck Dissection: A Randomized Clinical Trial. JAMA Otolaryngology-Head \& Neck Surgery, 143(12): 1195-1199.

29. Wang Y, Guan $Q$ and Xiang J (2019): Nomogram for predicting level $\mathrm{V}$ lymph node metastases in papillary thyroid carcinoma with clinically lateral lymph node metastases: A large retrospective cohort study of 1037 patients from FDUSCC. Journal of Cancer, 10(3): 772-783.

30. Won HR, Chang JW, Kang YE, Kang JY and Koo BS (2018): Optimal extent of lateral neck dissection for well-differentiated thyroid carcinoma with metastatic lateral neck lymph nodes: a systematic review and metaanalysis. Oral oncology, 87(3): 117-125.

31. Xiang D, Xie L, Xu Y, Li Z, Hong Y and Wang $P$ (2015): Papillary thyroid microcarcinomas located at the middle part of the middle third of the thyroid gland correlates with the presence of neck metastasis. Surgery, 157(3): 526-533.

32. Xu JJ, Yu E, McMullen C, Pasternak J, Brierley J, Tsang, R and Gilbert R (2017): Patterns of regional recurrence in papillary thyroid cancer patients with lateral neck metastases undergoing neck dissection. Journal of Otolaryngology-Head \& Neck Surgery, 46(1): 43-55.

33. Yüce I, Cağli S, Bayram A, Karasu F and Güney E (2010): Regional metastatic pattern of papillary thyroid carcinoma. European archives of oto-rhino-laryngology, 267(3): 437-441.

34. Zhang XJ, Liu D, Xu DB, Mu YQ and Chen WK (2013): Should level V be included in lateral neck dissection in treating papillary thyroid carcinoma? World journal of surgical oncology, 11(1): 304-315. 


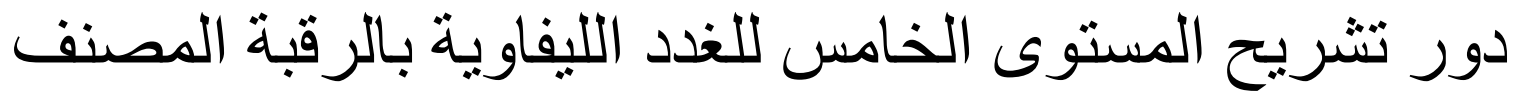 ايجابيتها 1 ب في حالات السرطان الحليمي للغدة الدرقية عيد رزق الجمال *، حامد محمد العزوني*، أحمد طارق على الشامى** *قسم جراحة الأورام، كلية الطب، جامعة الأزهر * |*قم جراحة الأورام، مركز أورام طنطا}

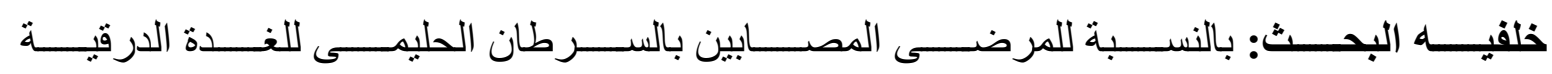

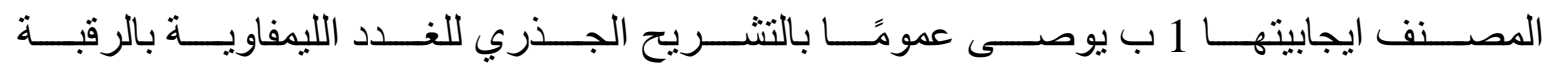

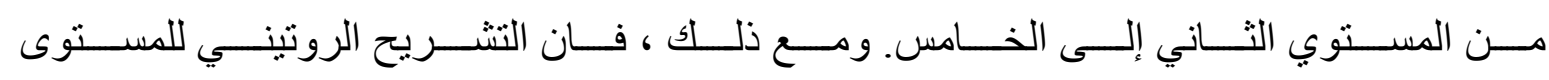

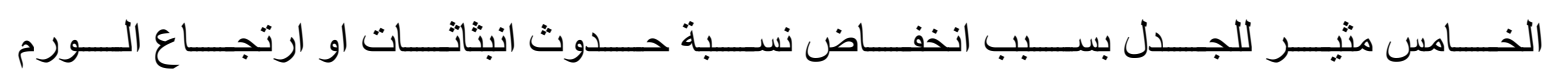
السرطانى في هذا المستوى وزيادة المضاعفات السريرية المصاحبة لتشريحة.

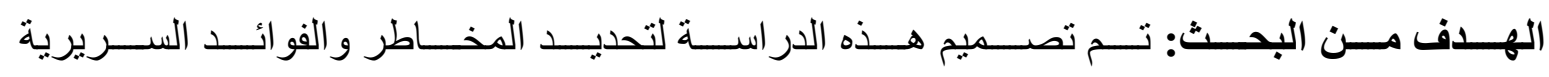

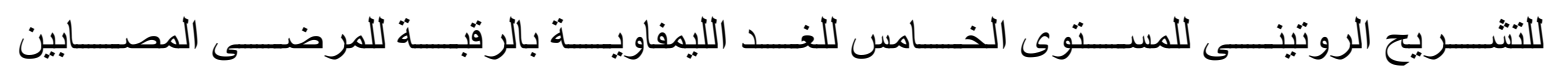

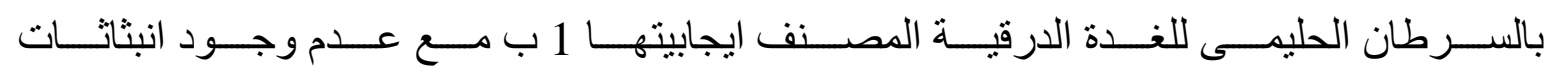
فى هذا المستوى.

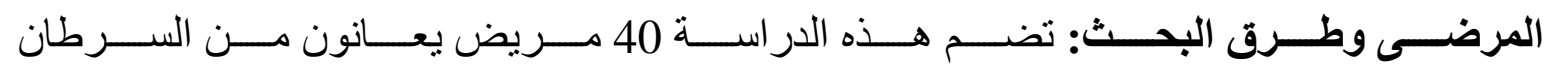

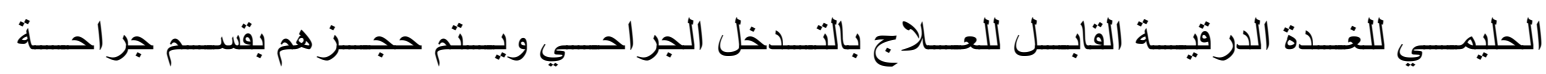

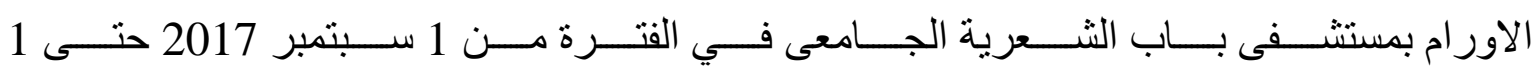

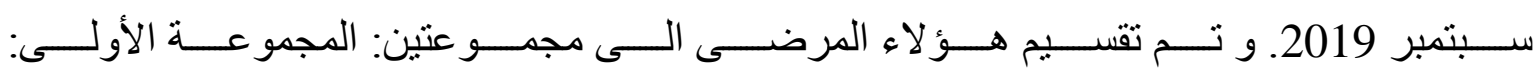

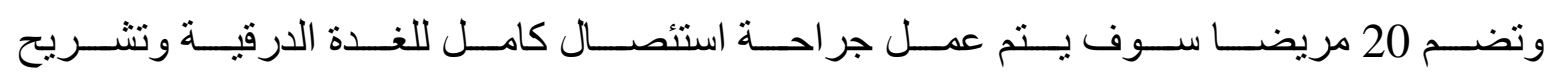

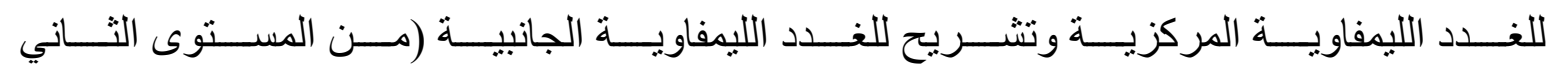

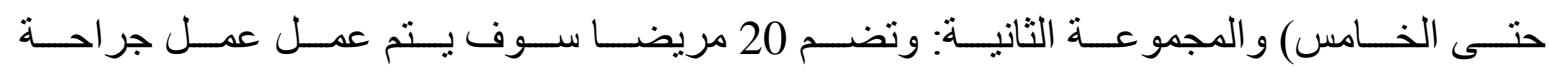

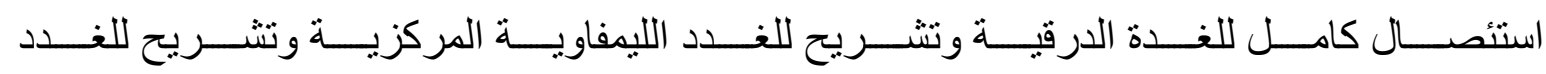
الليمفاوية الجانبية (من المستوى الثناني حتى الرابع). 


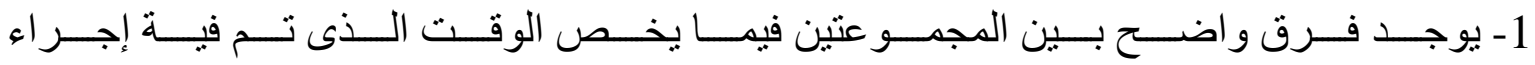

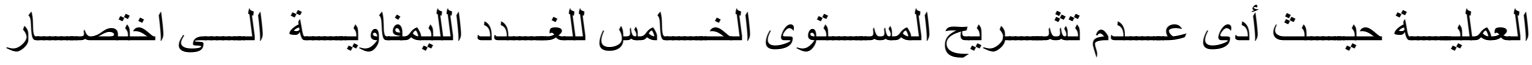
وقت العملية.

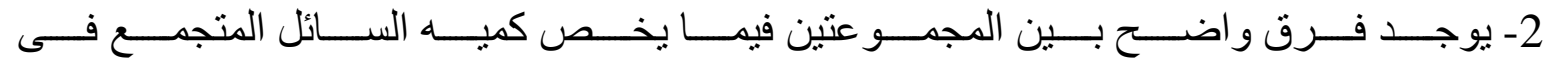

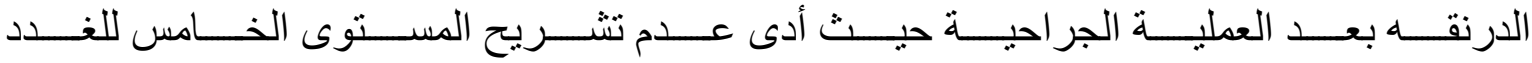
الليمفاوية الى تقليل هذه الكمية.

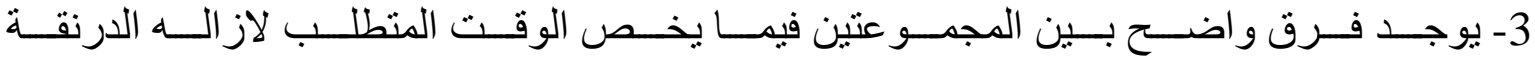

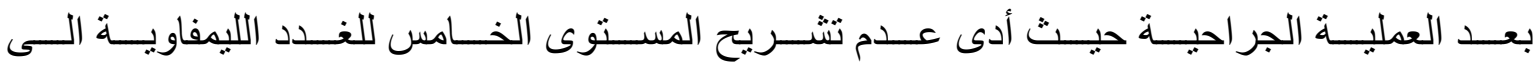
تقليل هذه المدة.

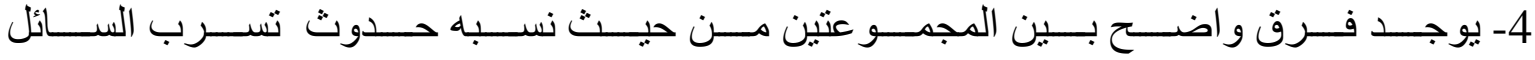

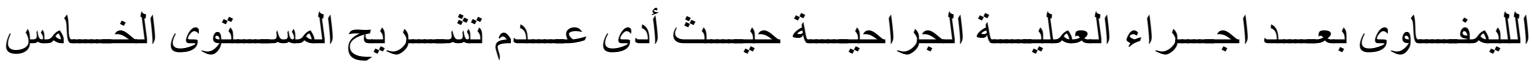
للغدد الليمفاوية الى تقليل هذه النسبة.

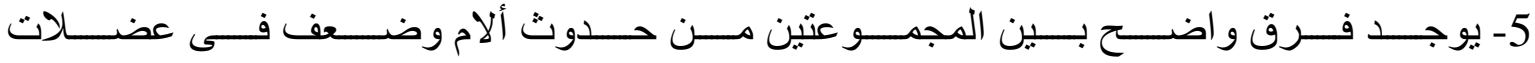

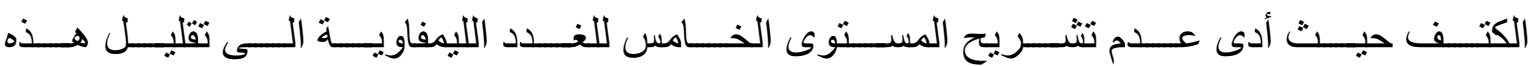
الظاهرة.

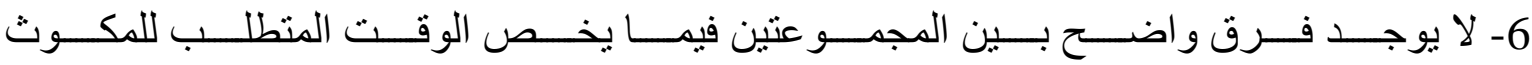

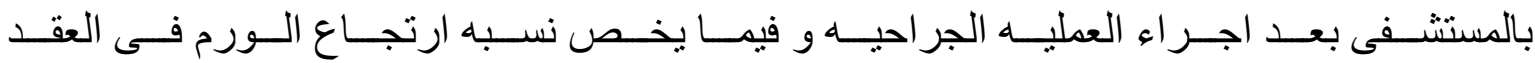
الليمفاوية.

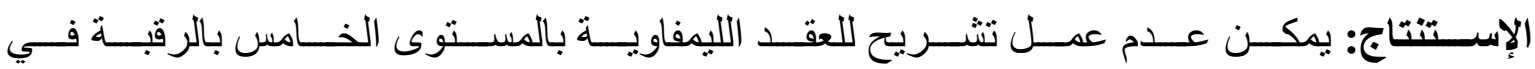
حالات السرطان الحليمي للغدة الدرقية المثبت عدم اصابتهم بانبثاثات. 